\title{
Enhancement of Energy Efficiency of Hydro Turbine Generators by Energy Conservation Techniques
}

\author{
Rajashekar P. Mandi, Udaykumar R. Yaragatti
}

\begin{abstract}
This paper describes the results of enhancing energy efficiency of hydro turbines by implementing the energy conservation measures for hydro turbine generators. The procedure for evaluating the on-line performance of generators is discussed. The energy saving in generators by maintaining optimum generator terminal voltage, by reducing the stator winding temperature by improving the performance of coolers and reducing the excitation loss by appropriate tuning of excitation system are enumerated in details with case studies. The implementation of energy conservation measures have a techno-economic feasibility with a payback period of 1 to 5 years.
\end{abstract}

Keywords: Generator; Hydro turbine; Energy efficiency; Stator copper loss; Rotor copper loss; Generator cooling; Generator excitation;

\section{INTRODUCTION}

The power generation has increased from $1.36 \mathrm{GW}$ during 1947 to $357 \mathrm{GW}$ as on March $31^{\text {st }} 2019$ [1]. The total installed capacity of Hydro power plant is $45.4 \mathrm{GW}$ that forms $12.7 \%$ of total installed capacity. Hydroelectric generation is a continuous production process in which hydraulic energy is converted into mechanical energy and finally converted into electric energy. It is a clean, renewable and low cost of energy production. Energy generation through hydropower makes great sense because this helps in reduction of fossil or nuclear fuel burning. The hydraulic energy is a valuable natural resource, and increasing the efficiency of hydropower production is a long term goal in the field of hydropower engineering because it greatly contributes to the economy and environment. Hydro stations need very less number of auxiliaries to run the plant and its auxiliary power will vary between 0.5 to $0.7 \%$ of gross energy generation [2]. The major hurdle in implementing the Hydro stations are site specific and stochasticity in nature.

At present many of the hydro stations are operating as run of the river plant due to non-availability of enough water source and regulations laid for water for irrigation purpose. This had caused lowering of plant load factor of hydro power stations. Many of the hydro stations are not provided with water flow measurement and are not evaluating the performance of the plants. The energy audit study in more than 55 hydro power plants had shown that there are ample scopes for improving the performance of hydro turbine generators and also reduction in auxiliary power.

Revised Manuscript Received on March 5, 2020.

Dr. Rajashekar P. Mandi, Director, School of Electrical and Electronics Engineering, REVA University, Bangalore

and Dr. Udaykumar R. Yaragatti, Director, Malaviya National Institute of Technology, Jaipur

\section{GENERATOR}

In most of the Hydro power stations, the generator (Indian manufactured) terminal voltage will be $11 \mathrm{kV}$ for the generators. Few imported units have different generator terminal voltage of $13.8 \mathrm{kV}$ also. This terminal voltage will be stepped up to grid voltage (i.e., $132 \mathrm{kV}, 220 \mathrm{kV}$ or 400 $\mathrm{kV}$ ) by either one 3-phase generator transformer (usually surface based power plants) or three numbers of single phase generator transformers (usually underground power plants).

The energy input (Wh) to turbine is hydraulic energy and can be computed as [3]

$E_{h}=\int_{t 1}^{t 2} g \rho H Q \cdot d t$

Where $g$ is acceleration due to gravity in $\left(\mathrm{m} / \mathrm{sec}^{2}\right), \rho$ is density of water in $\left(\mathrm{kg} / \mathrm{m}^{3}\right), \mathrm{H}$ is net head in $(\mathrm{m})$ and $\mathrm{Q}$ is mass flow of water $\left(\mathrm{m}^{3} / \mathrm{sec}\right), t_{1}$ is initial time and $t_{2}$ is final time in (h).

The energy output (Wh) from turbine generator is the electrical energy and is measured

$E_{O}=\int_{t 1}^{t 2} P_{O} \cdot d t$

Where $\mathrm{P}_{\mathrm{O}}$ is the output power measured at generator output terminals by using power analyser in (W)

The combined turbine and generator efficiency (\%) is computed by measuring hydraulic energy at water turbine input and electrical energy output at generator terminals. But it is slightly difficult to compute either turbine or generator efficiency individually. The hydro turbinegenerator efficiency (overall efficiency) is computed by [4, 5]

$\eta=\frac{E_{O}}{E_{h}}=\frac{\int_{t 1}^{t 2} P_{O} \cdot d t}{\int_{t 1}^{t 2} g \rho H Q \cdot d t}$

In order to evaluate the generator efficiency (\%), the loss evaluation method is adopted and is computed as:

$\eta_{g e n}=\frac{P_{\text {out }} * 100}{P_{\text {out }}+\left(L_{s c}+L_{r c}+L_{E x}+L_{\text {stray }}+L_{f \& w}+L_{\text {iron/core }}\right) * 1000}$

Where $\mathrm{P}_{\text {out }}$ is the power output at generator terminals in $\mathrm{MW}, \mathrm{L}_{\mathrm{sc}}$ is stator copper loss in $\mathrm{kW}, \mathrm{L}_{\mathrm{rc}}$ is rotor copper loss in $\mathrm{kW}, \mathrm{L}_{\mathrm{Ex}}$ is excitation loss in $\mathrm{kW}, \mathrm{L}_{\text {stray }}$ is stray load loss in $\mathrm{kW}, \mathrm{L}_{\mathrm{f} \& \mathrm{w}}$ is the friction and windage loss in $\mathrm{kW}$ and $\mathrm{L}_{\text {iron/core }}$ is the iron or core loss in $\mathrm{kW}$.

The stator copper loss $(\mathrm{kW})$ is proportional to square of the stator current \& winding resistance and is computed as: 
$L_{s c}=\frac{\left(I_{R}{ }^{2}+I_{Y}{ }^{2}+I_{B}{ }^{2}\right) * R_{a}}{1000}$

Where $I_{R}, I_{Y} \& I_{B}$ are stator current respectively for $R$ phase, Y-phase \& B-phase in Ampere, $\mathrm{R}_{\mathrm{a}}$ is the actual (working) stator winding resistance which will be extrapolated from the design winding resistance $(\Omega /$ phase $)$ at design temperature (i.e., $20^{\circ} \mathrm{C}$ ) and is computed as:

$R_{a}=R_{d} *\left(\frac{234.5+T_{a}}{234.5+T_{d}}\right)$

Where $R_{d}$ is stator winding resistance at design temperature in $\Omega /$ phase, $T_{d}$ is stator winding temperature at design value in degree centigrade $\left({ }^{\circ} \mathrm{C}\right)$ usually at $20^{\circ} \mathrm{C}, \mathrm{T}_{\mathrm{a}}$ is the measured or actual stator winding temperature in degree centigrade $\left({ }^{\circ} \mathrm{C}\right)$.

Generally three types of field excitation systems are being used:

a) Rotary magnetic system where exciter will be mounted on the same shaft of generator and the pilot exciter will excite the exciter and the main exciter will provide excitation for the field. The rotor copper loss $(\mathrm{kW})$ is computed as:

$$
L_{r c}=\frac{I_{f} * V_{f}}{1000}
$$

Where $I_{f}$ is the field current (DC) in Ampere and $V_{f}$ is the field excitation voltage (DC) in Volts.

b) Static excitation system where the power will be tapped at generator bus and the voltage will be stepped down to either $600 \mathrm{~V}$ or $400 \mathrm{~V}$ by the excitation transformer. The total excitation loss $(\mathrm{kW})$ will be measured by measuring voltage, current and power factor at excitation transformer primary side by using power analyzer. The total excitation loss including rotor copper loss is computed as:

$$
T L_{E x}=\frac{V_{R} * I_{R} * P F_{R}+V_{Y} * I_{R} * P F_{R}+V_{B} * I_{R} * P F_{R}}{1000}
$$

Where $V_{R}, V_{Y}$ \& $V_{B}$ are generator terminal phase voltage respectively for R-phase, Y-phase \& B-phase in Volts, $I_{R}, I_{Y} \& I_{B}$ are excitation current at primary side of Excitation transformer respectively for $\mathrm{R}$ phase, $\mathrm{Y}$-phase \& B-phase in Ampere and $\mathrm{PF}_{\mathrm{R}}, \mathrm{PF}_{\mathrm{Y}}$ \& $\mathrm{PF}_{\mathrm{B}}$ are power factor respectively for $\mathrm{R}$-phase, $\mathrm{Y}$ phase \& B-phase.

The rotor copper loss is computed similar way as given in above equation (4).

The excitation loss $(\mathrm{kW})$ i.e., conversion loss from AC to DC is computed by

$$
L_{E x}=T L_{E x}-L_{r c}
$$

Brushless excitation system: in this rotor copper loss $(\mathrm{kW})$ is evaluated by:

$$
L_{r c}=\frac{I_{f}{ }^{2} * R_{f}}{1000}
$$

Where $I_{f}$ is the field current (DC) in Ampere and $R_{f}$ is the field resistance in at operating temperature which can be extrapolated by using equation (3).

Stray load loss is difficult to measure on-line during performance test and will be taken as constant based on the design value. It is also difficult to measure the friction and windage loss on-line and will be taken as constant based on the design value.
The iron or core loss will be assumed approximately directly proportional to the frequency and voltage and is computed as

$$
L_{\text {iron/core }}=\frac{V_{\text {operating }} * F_{\text {operating }} * L_{\text {iron/core-design }}}{V_{\text {design }} * F_{\text {design }}}
$$

Where $\mathrm{V}_{\text {operating }}$ is operating phase or line voltage in Volts, $\mathrm{V}_{\text {design }}$ is design phase or line voltage in Volts, $\mathrm{F}_{\text {operating }}$ is operating frequency in Hertz and $F_{\text {design }}$ is design frequency in Hertz i.e., $50 \mathrm{~Hz}$.

\section{A. Performance Test}

The performance test is carried out by maintaining the load nearly constant at full load or part load for a period of 60 minutes (one hour) and logged all the performance parameters simultaneously throughout the test period of 60 minutes. The variations in critical parameters are monitored. The power supply parameters at generators are logged in the power analyzers. The field current \& field voltage, stator winding \& core temperature readings are recorded from the control desk. The auxiliary power is logged at primary side of UAT by using power analyzer. The power (for static excitation system) at excitation transformer primary side is measured by using power analyzer and the power at GT output is also measured through power analyzer. All these power measurements were carried out simultaneously during the performance test for a period of one hour by power analyzers of having same make and same accuracy level.

\section{B. Power plant 1}

At a typical hydro power plant 1 , four numbers of $120 \mathrm{MW}$ generators are evaluated for their performance and the results of one of the four generators are discussed. The generator terminal voltage is $13.8 \mathrm{kV}$ and is stepped up to $400 \mathrm{kV}$ through three numbers of single phase generator transformers of 50 MVA for each unit. The rated full load stator current is $5690 \mathrm{~A}$.

The generator cooling is provided through ventilating air circulation. Six surface air coolers are mounted on generator stator frame. Flow of cooling air through the machine is maintained partly by two opposing axial flow fans, mounted on the rotor rim and partly by the centrifugal pumping action of the rotor. The axial flow fans force the air into the air gap and the space between the poles and out through ducts in the core into the stator frame. Some of the air passes by parallel paths over the stator end windings through holes in the stator top and bottom rings into the stator frame. The centrifugal action created by the rotor draws the air into the rotor centre through holes in the upper disc and the air is forced out through air ducts in the rotor rim into the air gap and the pole gaps and finally forced out through ducts in the core into the stator frame. Four numbers of surface air coolers are placed around the outside of the stator frame for each generator. The portable water passes through the surface air coolers and the water cools the air passing through the cooler. The air coolers are provided with 90/10 copper-nickel alloy tubes wound with copper wire fixed in a MS frame. The portable water is again cooled in the shell and tube heat exchangers. Each unit is provided with one heat exchanger along with one raw water pump and one portable water pump. 
One standby heat exchanger along with raw and portable water pumps are provided in case of failure of unit heat exchangers [6].

The measured energy, voltage, current and computed load $\&$ voltage unbalance between 3 -phases at generator output during the performance tests are presented in Table 1 . The voltage at generator terminal during test 1 was on lower side in the range of $13.35 \mathrm{kV}-13.37 \mathrm{kV}$ which is lower than the design value of $13.8 \mathrm{kV}$ due to lower grid voltage at reduced terminal voltage the stator copper loss will be more. The voltage unbalance between 3 -phases is in the range of 0.09 to $0.15 \%$ which is lower than the limit given by International standards (EN-50160 or IEC 1000-3-X series) $<2 \%$ for LV \& MV system. The current unbalance between 3-phases is in the range of $2.44-2.95 \%$ and is also normal but it depends on the grid condition.

\section{Table 1: Measured voltage, current, and voltage \& current unbalance between 3-phases at}

\begin{tabular}{|c|c|c|c|c|c|c|c|c|c|}
\hline Te & \multirow{2}{*}{$\begin{array}{c}\text { Energy, } \\
\text { st }\end{array}$} & \multicolumn{3}{|c|}{ Terminal voltage, kV } & \multicolumn{4}{c|}{ Stator current, A } \\
\cline { 3 - 10 } & & RY & YB & $\mathbf{B R}$ & $\begin{array}{c}\text { Un, } \\
\mathbf{\%}\end{array}$ & $\mathbf{R}$ & $\mathbf{Y}$ & $\mathbf{B}$ & $\begin{array}{c}\text { In, } \\
\mathbf{\%}\end{array}$ \\
\hline 1 & 45.7 & 13.4 & 13.4 & 13.4 & 0.09 & 2077.6 & 2153.0 & 2191.3 & 2.95 \\
\hline 2 & 103.2 & 13.8 & 13.8 & 13.8 & 0.14 & 4603.2 & 4742.9 & 4809.0 & 2.44 \\
\hline 3 & 117.1 & 13.8 & 13.8 & 13.8 & 0.15 & 5132.2 & 5297.6 & 5367.2 & 2.53 \\
\hline
\end{tabular}

The measured frequency, power, power factor, stator winding

temperat

Table 2: Measured frequency, power factor, power, stator winding temperature, field voltage and currents at generators.

\begin{tabular}{|c|c|c|c|c|c|c|c|c|}
\hline Test & $\begin{array}{c}\begin{array}{l}\text { Frequ } \\
\text { ency, } \\
\mathrm{Hz}\end{array}\end{array}$ & $\begin{array}{c}\text { Power, } \\
\text { MW }\end{array}$ & $\begin{array}{l}\text { Power } \\
\text { factor }\end{array}$ & $\begin{array}{c}\text { Stator } \\
\text { Windin } \\
\text { g temp. } \\
\text { Avg., } \\
{ }^{\circ} \mathrm{C}\end{array}$ & $\begin{array}{c}\text { Cold } \\
\text { air } \\
\text { temp. } \\
{ }^{\circ} \mathrm{C}\end{array}$ & $\begin{array}{c}\text { Hot } \\
\text { air } \\
\text { temp., } \\
{ }^{\circ} \mathrm{C}\end{array}$ & $\begin{array}{c}\text { Field } \\
\text { Curren } \\
\mathbf{t}, \mathbf{A}\end{array}$ & $\begin{array}{c}\text { Field } \\
\text { Voltage } \\
, \mathrm{V}\end{array}$ \\
\hline 1 & 49.54 & 45.73 & 0.92 & 53.83 & 25.00 & 45.33 & 713.3 & 71.63 \\
\hline 2 & 49.27 & 105.07 & 0.93 & 80.50 & 26.67 & 54.00 & 1272.2 & 135.48 \\
\hline 3 & 49.42 & 119.22 & 0.95 & 90.50 & 28.00 & 57.67 & 1314.5 & 143.96 \\
\hline
\end{tabular}

ure, circulating water inlet $\&$ outlet temperature values are given in Table 2 . Figure 1 gives the variation of stator winding temperature during the performance test. The stator winding temperature is increased from $52{ }^{\circ} \mathrm{C}$ to $55{ }^{\circ} \mathrm{C}$ (increase rate of $1.09 \times 10^{-3}{ }^{\circ} \mathrm{C} / \mathrm{min} / \mathrm{MW}$ ) of during Test 1 at an average load of $45.73 \mathrm{MW}$ because the unit was running at lower load just before the start of Test. Therefore, the stator winding temperature is increased. The load on generator is increased to an average load of 105.07 MW in a time span of 90 minutes at a ramp rate of 0.66 $\mathrm{MW} / \mathrm{min}$. The stator winding temperature is increased from $65{ }^{\circ} \mathrm{C}$ to $76{ }^{\circ} \mathrm{C}$ (increase rate of $2.06 \times 10^{-3}{ }^{\circ} \mathrm{C} / \mathrm{min} / \mathrm{MW}$ ). During Test 2, the winding temperature was nearly constant at $80^{\circ} \mathrm{C}$. The load on the generator is increased to an average value of 119.22 MW in a time span of $60 \mathrm{~min}$. with a ramp rate of $0.24 \mathrm{MW} / \mathrm{min}$. The winding temperature is increased from 81 to $89{ }^{\circ} \mathrm{C}$ (increase rate of $1.74 \times 10^{-3}{ }^{\circ} \mathrm{C}$ $/ \mathrm{min} / \mathrm{MW}$ ) and during Test 3 , the stator winding temperature is increased from 83 to $86{ }^{\circ} \mathrm{C}$ (increase rate of $\left.0.42 \times 10^{-3}{ }^{\circ} \mathrm{C} / \mathrm{min} / \mathrm{MW}\right)$. Similarly, the stator core temperature is also increased from $50{ }^{\circ} \mathrm{C}$ to $55{ }^{\circ} \mathrm{C}$ during Test 1 (increase rate of $1.82 \times 10^{-3}{ }^{\circ} \mathrm{C} / \mathrm{min} / \mathrm{MW}$ ), increased from 79 to $81{ }^{\circ} \mathrm{C}$ during Test 2 (increase rate of $0.32 \times 10^{-3}$ ${ }^{\circ} \mathrm{C} / \mathrm{min} / \mathrm{MW}$ ) and increased from 89 to $92{ }^{\circ} \mathrm{C}$ during Test 3 (increase rate of $0.42 \times 10^{-3}{ }^{\circ} \mathrm{C} / \mathrm{min} / \mathrm{MW}$ ). It can be seen from the Figure that the stator winding and core generators.

temperatures are increased as the plant load increases due to increased stator and rotor copper loss. The stator winding and core temperatures are on par with design value of (rise: $75{ }^{\circ} \mathrm{C}$ above ambient temp.).

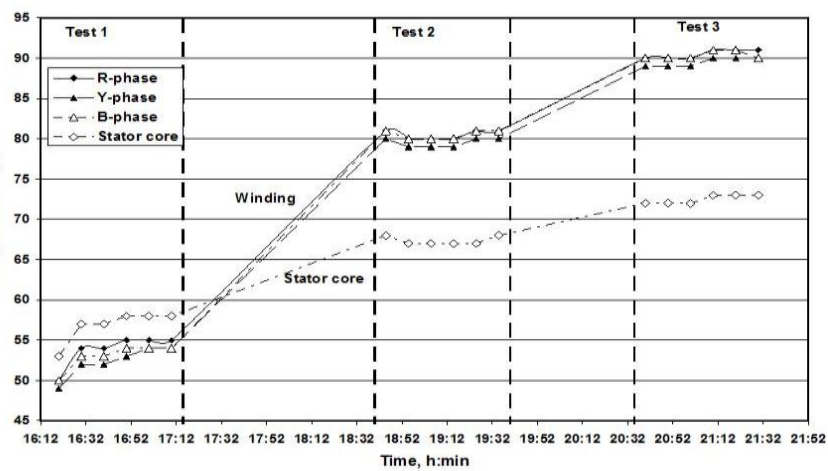

Figure 1: Variation of stator winding and core

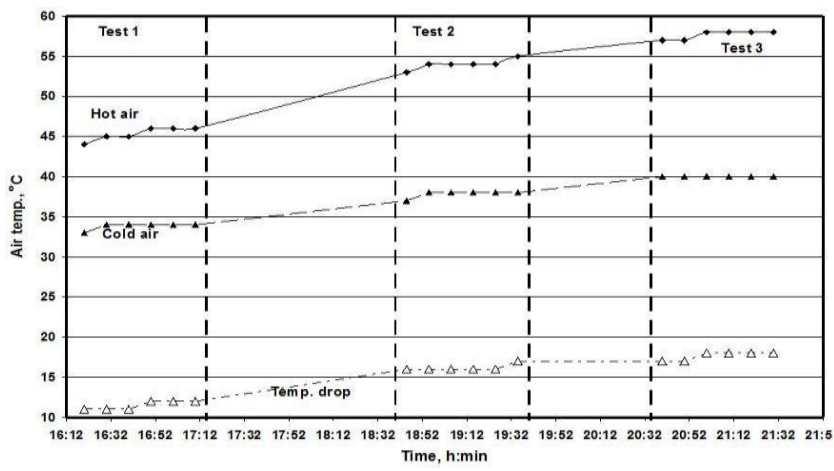

Figure 2: Variation of cold and hot air temperature

iigure 2 gives the variation of cold air and hot air emperature during performance test. It can be seen from he Figure that as the plant load increases the hot air and old air temperatures are increased and the temperature rop across cooler also increased. The cold air temperature at surface air coolers is slightly higher side may be due to scaling in tubes or blockage of tubes [7, 8]. However the air outlet temperature is lower than the maximum limit of 41.4 ${ }^{\circ} \mathrm{C}$ at air inlet temperature of $67{ }^{\circ} \mathrm{C}$. The drop in temperature across surface air coolers is varying between $11-18{ }^{\circ} \mathrm{C}$. The cleaning of tubes of surface air coolers had improved the effectiveness of cooler that reduced the winding temperature. This had reduced the energy consumption by $3.4 \mathrm{MWh} /$ month (the winding temperature is reduced by about $3^{\circ} \mathrm{C}$ ).

The computed apparent power, plant load factor, stator copper loss, total loss and generator efficiency are given in Table 3. Figure 3 gives the variation of active and reactive power during the performance test.

Table 3: Performance results of generators.

\begin{tabular}{|c|c|c|c|c|c|c|c|}
\hline Test & $\begin{array}{c}\text { Apparent } \\
\text { power, } \\
\text { MVA }\end{array}$ & $\begin{array}{c}\text { Plant } \\
\text { load, } \\
\text { \% }\end{array}$ & $\begin{array}{c}\text { Stator } \\
\text { Copper } \\
\text { Loss, } \\
\text { kW }\end{array}$ & $\begin{array}{c}\text { Rotor } \\
\text { copper } \\
\text { loss, } \\
\text { kW }\end{array}$ & $\begin{array}{c}\text { Total } \\
\text { Excitation } \\
\text { loss, kW }\end{array}$ & $\begin{array}{c}\text { Total } \\
\text { loss, } \\
\text { kW }\end{array}$ & $\begin{array}{c}\text { Gen } \\
\text { eff., \% }\end{array}$ \\
\hline 1 & 49.434 & 33.63 & 75.20 & 51.10 & 73.51 & 1302.05 & 97.23 \\
\hline 2 & 113.104 & 77.26 & 399.08 & 172.35 & 223.50 & 1786.47 & 98.30 \\
\hline 3 & 126.108 & 87.66 & 512.82 & 189.24 & 243.40 & 1921.13 & 98.39 \\
\hline
\end{tabular}




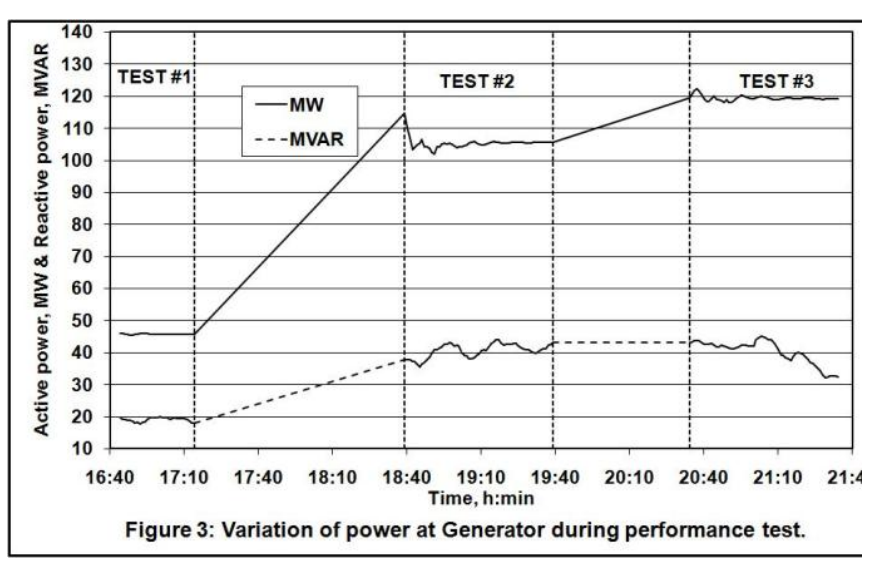

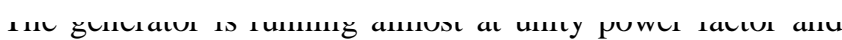
reactive power sharing by this generator is less but the power factor on this machine is derived from the grid conditions. Therefore, the increased losses in stator winding due to poor power factor is less. The load on generator is maintained nearly constant for a period of one hour for each test. About 5 minutes is taken for settling period while changing the load. The energy and all other parameters for each test are taken for 55 minutes and extrapolated for a period of one hour.

The stator copper losses at generator are computed for all three tests in the range of $75.2-512.8 \mathrm{~kW}$. The losses are on lower side may be due to lower winding temperature and operating at almost unity power factor.

The rotor copper losses at generator are computed based on the measured excitation voltage \& current at generator for three tests and are varying in the range of $51.10-189.24$ $\mathrm{kW}$. The rotor copper losses are on lower side because all the generators are operating at unity power factor always. At unity power factor the excitation power required will be less in generators. The total excitation losses (from AC power at excitation transformer input to DC power at field windings) are measured by using power analyzers and are varying in the range of $73.51-243.40 \mathrm{~kW}$. These total excitation losses are also lower than the design value of 250 $\mathrm{kW}$ at 0.90 power factor. These losses are on lower side may be because of operating the generators at unity power factor. At unity power factor the excitation power required will be less in generators.

The generator efficiencies for three tests are computed and are in the range of 97.23 - $98.39 \%$. The generator efficiencies are on par with design values of $98.42 \%$ at 0.90 $\mathrm{PF}$ and $98.49 \%$ at unity PF.

\section{Power plant 2}

In a case study to evaluate the performance of Hydro power station generators, three generators of $35.1 \mathrm{MW}$ for water turbines are considered. The generator cooling is provided through ventilating air circulation. Eight air coolers are mounted on generator stator frame and the cooled air is supplied into the space between coolers and generator barrel from which part of this air will be return to the fan below the rotor through the ducts in the foundation below the air coolers and the remainder of the cooled air will return in the fan above the rotor. The air is then circulated through the closed system by the combined action of the rotor poles and of the fans. The air in the cooler is cooled by the circulating water. The air coolers are provided with 90/10 copper- nickel alloy tubes wound with copper wire fixed in a MS frame. The generator terminal voltage is $11 \mathrm{kV}$ and the rated full load stator current is $2050 \mathrm{~A} .11 \mathrm{kV}$ is stepped up to $132 \mathrm{kV}$ through three single phase generator transformers for each unit.

Performance tests were conducted on generators of units 1 to 3 at different load conditions varying from $8 \mathrm{MW}$ to 32 MW.
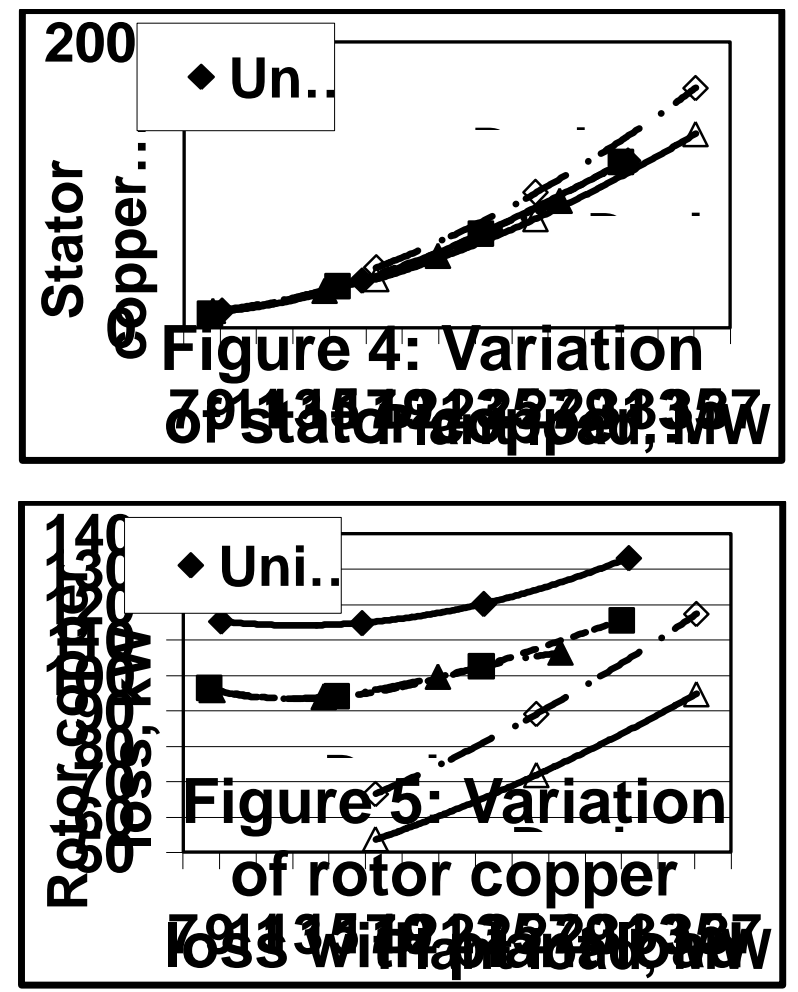

Figure 4 gives the variation of stator copper loss with plant load factor during performance test. Figure 5 gives the rotor copper loss with plant load factor. Figure 6 gives the variation of stator winding temperature with plant load factor during performance test. The temperature drop across generator air coolers is given in Figure 7. The generator efficiency is computed and is presented in Figure 8. The energy conservation measures from the detailed energy audit study are as follows:

a) The load unbalance between 3-phases is computed by taking the deviation in current at all 3-phases. The load unbalance between 3-phases at stator terminal varies between $9.19 \%-12.11 \%$ at Unit \#1, $7.16 \%-10.80 \%$ at Unit \#2 and $7.39 \%-10.87 \%$ at Unit \#3. The load unbalance is on higher side and the increased stator copper loss due to load unbalance is varying between $0.05-0.27 \mathrm{~kW}$. The increased load unbalance also reduced the generator capacity. The load unbalance is primarily dependent on the loading pattern of grid and little control action from individual plant.

b) The maximum stator winding temperature was varying in the range of $58.1{ }^{\circ} \mathrm{C}-75.3{ }^{\circ} \mathrm{C}$ at Unit $\# 1,69.3{ }^{\circ} \mathrm{C}-$ $80.1{ }^{\circ} \mathrm{C}$ at Unit \#2 and $60.96{ }^{\circ} \mathrm{C}-75.0{ }^{\circ} \mathrm{C}$ at Unit \#3. The overhauling of air coolers and replacement of blocked tubes reduced the winding temperature below $75^{\circ} \mathrm{C}$. This had reduced the energy consumption by 5.9 $\mathrm{MWh} / \mathrm{month}$. 
c) The temperature drop across air coolers was varying between $6.7{ }^{\circ} \mathrm{C}-8.93{ }^{\circ} \mathrm{C}$ at Unit $\# 1,7.73{ }^{\circ} \mathrm{C}-8.13{ }^{\circ} \mathrm{C}$ at Unit \#2 and $11.88{ }^{\circ} \mathrm{C}-13.54{ }^{\circ} \mathrm{C}$ at Unit \#3. The performance results of air coolers of Units $1 \& 2$ are poor and that of Unit \#3 are normal.

d) The terminal voltage at generator was varying between $10.4 \mathrm{kV}-10.9 \mathrm{kV}$ (variation of $-5.45 \%$ to $-0.91 \%$ ) and is very low compared to design value of $11 \mathrm{kV}$. The grid voltage (i.e., GT output) is varying between $130 \mathrm{kV}-136 \mathrm{kV}$ (variation of $-1.52 \%$ to $+3.03 \%$ ) and is normal. The generator transformer tap was in $2^{\text {nd }}$ position and was changed to $3^{\text {rd }}$ tap that had increased the generator terminal voltage by $2.5 \%$. Changing of generator tap to $3^{\text {rd }}$ position had reduced the stator copper loss by $14.5 \mathrm{MWh} / \mathrm{month}$ with same power output and also enhanced the current carrying capacity of generators by $3.18 \%$.

e) The overall stator copper losses are lower than the design value at $0.90 \mathrm{PF}$ (design value) and higher than the design value at Unity Power Factor (UPF). Most of the time all the generators operating near to unity power factor (UPF). The stator copper losses are higher due to higher load unbalance between 3-phases and slightly higher winding temperature and the losses are varying between $9.55-117.09 \mathrm{~kW}$.

f) The total excitation loss was varying in the range of $115.2 \mathrm{~kW}-133.2 \mathrm{~kW}$ at Unit \#1, $96.46 \mathrm{~kW}-115.56$ $\mathrm{kW}$ at Unit \#2 and $96.0 \mathrm{~kW}-106.46 \mathrm{~kW}$ at Unit \#3. The excitation losses were on higher side compared to design values. The excitation losses can be controlled by proper tuning of Analogue Voltage Regulator (AVR) system. The present excitation system can be replaced with new static Digital Voltage Regulator (DVR) excitation system which will reduce the excitation losses from average value of $124.38 \mathrm{~kW}$ to $95.94 \mathrm{~kW}$. This measure reduces the energy consumption by $61.4 \mathrm{MWh} /$ month.

g) The generator efficiencies were varying between 92.16 - $97.22 \%$ at Unit \#1, 91.82 - 97.25\% at Unit \#2 and $91.94-97.04 \%$ at Unit \#3. The generator efficiencies are slightly lower than the design value.

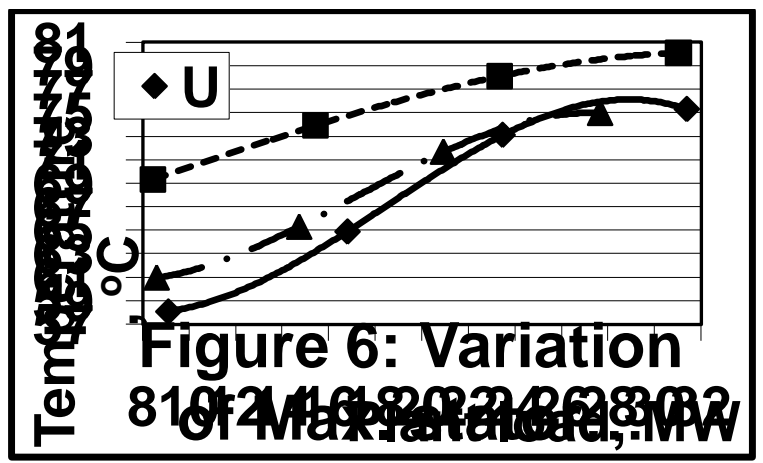

At lower generator terminal voltage increases the stator copper loss but very high voltage will strain the stator winding insulation that reduces the life of generators. Setting the generator voltage near to design value reduces the stator copper loss. The unbalanced stator current increases the stator copper loss that reduces the capacity of generators. The higher winding temperature increases the stator copper loss and the winding temperature can be reduced by cleaning the surface air coolers. Optimizing the stator water flow through coolers by circulating water pumps reduces the energy consumption. Tuning the static excitation system reduces the excitation losses and replacement of AVR by DVR for static excitation system reduces the energy losses in excitation system.

\section{REFERENCES}

1. CEA, 2019, website: http//:www.cea.nic.in.

2. IEEE Std 492-1999, IEEE Guide for Operation and Maintenance of Hydro- Generators.

3. Ye L et al., "An integral criterion appraising the overall quality of a computer-based hydro turbine generating system", IEEE Trans Energy Conversion 1995; 10(2): pp. 376-381.

4. Ye L, et.al., "Intelligent control-maintenance-management system and its applications on hydropower system", Management and Control of Production and Logistics 2000, IFAC/IFIP/IEEE, Pergamon, Vol. 2, 2000, pp. 609-614.

5. Yongqian Liu, et. al., "Economic performance evaluation method for hydroelectric generating units", Energy Conversion and Management, Pergamon, Vol. 44 (2003), pp. 797-808

6. Geoff Klempner \& Isidor Kerszenbaum, "Operation and Maintenance of Large Turbo-Generators", IEEE Press, WileyInterscience. 2004.

7. IEEE 432-1992, IEEE Guide for Insulation Maintenance for Rotating Electrical Machinery (5hp to less than 10000hp).

8. Isidor Kerszenbaum, "Inspection of Large Synchronous Machines. Checklists, Failure Identification, and Troubleshooting”. IEEE Power Engineering Series, 1996. 


\section{AUTHORS PROFILE}

Dr. Rajashekar P. Mandi, Director, School of Electrical and Electronics Engineering, REVA University, holds Doctorate from NITK, Surathkal in the area of "Power and Energy" and holds M. Tech. degree with 3rd Rank in "Energy Systems Engineering" from BV Bhoomaraddi College of Engineering \& Technology, Hubli of Visveswaraiah Technology University (VTU), Belgaum. He has five year of teaching experience. Prior to venturing into the field of academia, he has worked in Central Power Research Institute (CPRI) for 26 years in the area of Energy conservation, Energy audit, Power quality, Power system and Renewable energy systems. His teaching experience includes, teaching subjects like - Power quality, FACTS controller, Electric Vehicle, Energy management, Renewable energy systems, etc., at the post-graduate level and $\mathrm{PhD}$ research scholars, and Electric power utilization, Electric machines, etc., at the undergraduate level. His area of interest is Energy conservation, Power quality, Power system and Renewable energy system. $\mathrm{He}$ is a professional member of IEEE. He is a member of CII task force committee for Power and Infrastructure in Karnataka. He is accredited energy auditor from Bureau of Energy Efficiency (BEE), Govt. of India. $\mathrm{He}$ is presently chairman of Society for Energy Efficiency \& Manager (SEEM) Karnataka Chapter. He was member of several BIS committee in the area of electric lamps, electrical fans, solar PV, Batteries, electrical appliances, etc. He was also member of fixing of star label for LED lamps and electrical appliances for Bureau of Energy Efficiency, Govt. of India. He worked as nodal officer in Accelerated Power Development \& Reforms Programme (APDRP). His research interests include renewable energy systems, energy conservation, strengthening of electrical distribution systems, electrical safety, power quality, LED lighting systems, etc. $\mathrm{He}$ had written 3 book chapters on energy conservation in Thermal Power plants and 2 book chapters in distributed power generation. He had published more than 155 technical papers in International \& Indian Journals, Conferences \& Seminars in the field of energy conservation, power quality, LED lighting system and renewable energy systems.

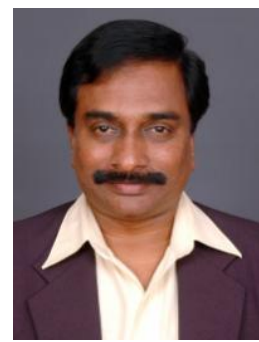

Udayakumar R. Yaragatti is Director, Malaviya National Institute of Technology (MNIT), Jaipur. Previously he was Dean, Head \& Professor at Department of Electrical and Electronics Engineering, National Institute of Technology Karnataka, Surathkal. He received Ph.D. in Energy Systems Engineering from Indian Institute of Technology, Bombay, M.Tech. in Industrial Electronics and B.Tech in Electrical Power from NITK Surathkal (formerly KREC).

His working experience includes teaching and research in the area of Power Electronics, Solid State Drives, PV System and Applications, Electrical Machine Design, Electrical Measuring Instruments, Electrical Machines, Principles and Practices of Management, Electrical Energy Systems, Energy Management, Energy Auditing, etc. He is specialized in Power Electronics and Drives, Energy Systems Engineering, Photovoltaic/Wind Power Systems, etc. He has published more than 150 technical papers in International \& Indian Journals, Conferences \& Seminars in the field of Electrical Power, Industrial Electronics, Energy Conservation and Renewable Energy Systems. 